\title{
Valcamonica Rock Art Weapons
}

\author{
Cristina Lopes \\ Joukowsky Institute for Archaeology and the Ancient World, Brown University, Providence, RI 02912, United States
}

Copyright $(2016$ by authors, all rights reserved. Authors agree that this article remains permanently open access under the terms of the Creative Commons Attribution License 4.0 International License

\begin{abstract}
Valcamonica is one of the most famous sites with rock art that particularly points out the weapons, and show us in the carved stones and archaeological remains glimpses of the past. It offers a fascinating and intriguing journey, for the many aspects that goes beyond the technical-utilitarian assessments. This journey enters in the field of art, the symbolic, the religious rituals and celebrations with the corollaries arising therefrom (On this arguments see Anati [1,2]). The weapons then, understood primarily as a substantial indicator of the psycho-physical development process of our species, are as a mirror of technical, social and ideological development [3] and have a major importance in this work.
\end{abstract}

Keywords Valcamonica, Rock Art, Weapons

\section{Introduction}

Valcamonica or Val Camonica is a valley of glacial origin, located in the Italian Alps, in the province of Brescia. The term Val Camonica derives from the Latin Vallis Camunnorum, which means the valley of Camuni, the people who inhabited the region for several centuries before the arrival of the Romans. There are recorded over 500,000 engravings, distributed from the Neolithic to the Middle Ages. However, about $80 \%$ belong to the Iron Age. The rock art of Valcamonica is divided into various localities, included the eight thematic parks [4,5]. A walk through Valcamonica is truly an evocative itinerary through history, as told by art.

The rock art is a greater witness of past societies as well in parallel show us the discovery data of almost all the material remains: the weapons by which this place is so well known, along with the carved representations were found normally in funerary objects and votive deposits, with countless examples of ad hoc fabrications, or non-functional, which means no signs of use beside the purely symbolic (further details on Sansoni [3] p. 17).

In this region is to highlight the so-called Massi di Cemmo in Capo di Ponte, which is composed with recorded blocks with typical Chalcolithic figures: Suns, axes, halberds, daggers, and schematic deer, among others [6]. The larger and more intensely carved are respectively Cemmo 1 (Fig.1) and Cemmo 2 that was later discovered in excavation, as other blocks and some statue-menhir, all dating from Chalcolithic.

The importance of this site led to the creation of a National Archaeological Park - Parco Archeologico Nazionale dei Massi di Cemmo that is placed nearby headquarters of the "Centro Camuno di Studi Preistorici", that has been developing important research work[7-10], and that whose logo interestingly is the reproduction of an existing Chalcolithic theme on "Capitello dei due Pini". The carved stone contain a solar representation, under which are five knives, two associated halberds and a schematic deer.

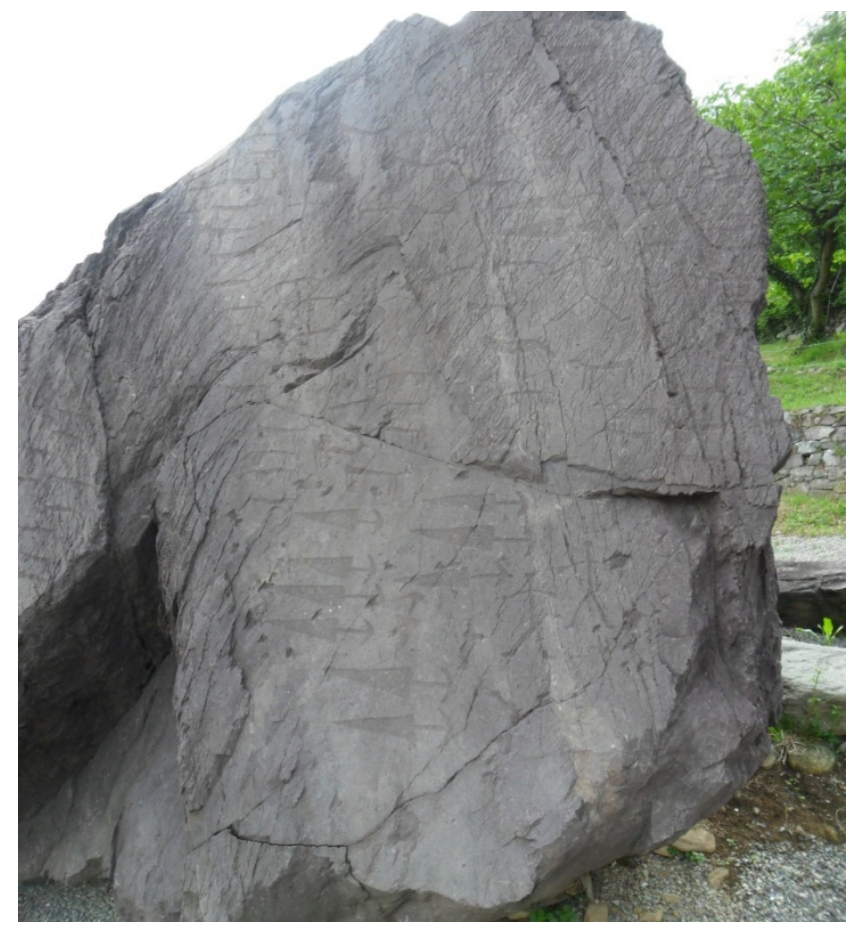

Figure 1. Cemmo 1 (Author photograph)

The menhir statues are common in many European countries, with a chronology that goes from the Chalcolithic until, in some cases, the Iron Age [7]. One of the most notable concentrations is located in Valcamonica, but we can 
also find them in the central Mediterranean area (Sardinia, Corsica and Lunigiana) in the south of France and the Iberian Peninsula (ibid.). The weapons found in archaeological digs thus permit the parallelism between the knives found in situ and the ones represented in the rock art, which enables to produce safe dating.

\section{Stages in Valcamonica Rock Art}

The first but dubious certification of weapon is in the earliest phase, the Epipaleolithic probably around VII-VI millennium $\mathrm{BC}$, the phase of the hunters and gatherers dating from the Alpine valleys by the last glacial. On unique stained surfaces, appeared the silhouettes of great wildlife, moose, deer, included pecked lines that if contemporary, shows a context that still an exclusive focus in the hunting prey, while probably also covered sacral values. The prey was actually hunted with spears in ambushes documented at high altitude, up to the ridges. To these first expressions follows a long hiatus, and we must wait the emergence of the Neolithic to find new signs on the rock [3, pp. 17-18].

Around the late fifth-early fourth Millennium on hold Valcamonica stone surfaces flourishes the expression of the farming and breeder communities. It is a schematic art, essential based on the human figure representations or on maps, (Cultivated land, fences, perhaps housing), rare animals, mostly ox skulls, and geometric figures. In any case there is a safe figuration of weapons. Anthropomorphic figures, in the position of praying with his arms raised up, have rarely simple lines on the hands in which it is very difficult to identify any precise object.

Only towards the last centuries of the fourth millennium, at the beginning of the Copper Age, appears the first unequivocal proof of weapon. Copper daggers or flint and perhaps axes that accompany the maps, the worshipers and finally the first scenes of plowing, is the age of the man from the ice, the age which attest the great continental transformations with gradual emergence of outstanding innovations, metallurgy, animal towing and secondary products such as dairy products and wool. The phenomenon has the characteristics of a cultural wave, which is accompanied and supported by an ideological-religious strong change.

the few figures of daggers on the rocks of Valcamonica and Mount Bego match daggers, axes and arrowheads, of late Neolithic tradition, which begin to be deposited on individual burials in the plains (Remedello, Volongo, Fontanella Mantovana in East Lombardy) and in the collective in the pre-Alpine area (Manerba del Garda, Villanuova sul Clisi, Bione). (ibid.p.18).

To the third millennium in Late Copper Age, when they mature all the conditions in the field, on the wave of a new cultural expansion, it was time to the true emergence of the world miners, blacksmiths, evolved farmers, weavers, merchants and warriors, until the birth of the historical European civilization. The weapons immediately take a primary relief on the remains and in funerary deposits, votive and rock art deposits, in an extended continental range.

In the last phase (bell beakers, beginning of Bronze Age) representations tend to be bi or single-figurative. It appears the first case of a panel with just representations of weapons, the "Corni Freschi" in Darfo, on a large landslide block. Appear in the top, two neat rows halberds and in the bottom, currently under ground level, two daggers. That represent the sign of extreme symbolic synthesis which seems to incorporate in the weapons, pars pro toto, the meanings of a whole set.

We do not know if this reflects an increase in weapon value for conflict, Traumatic events or tensions in the social context of that Time, but certainly there was change. With a special cultural patchwork, that quickly leads at the end of the cycle. Among the last glimpse, the third and the beginning of the second millennium all the expression stops in the Central Alps and essentially everywhere goes wearily, perhaps only a few engraving rock are to be found $[3,11]$.

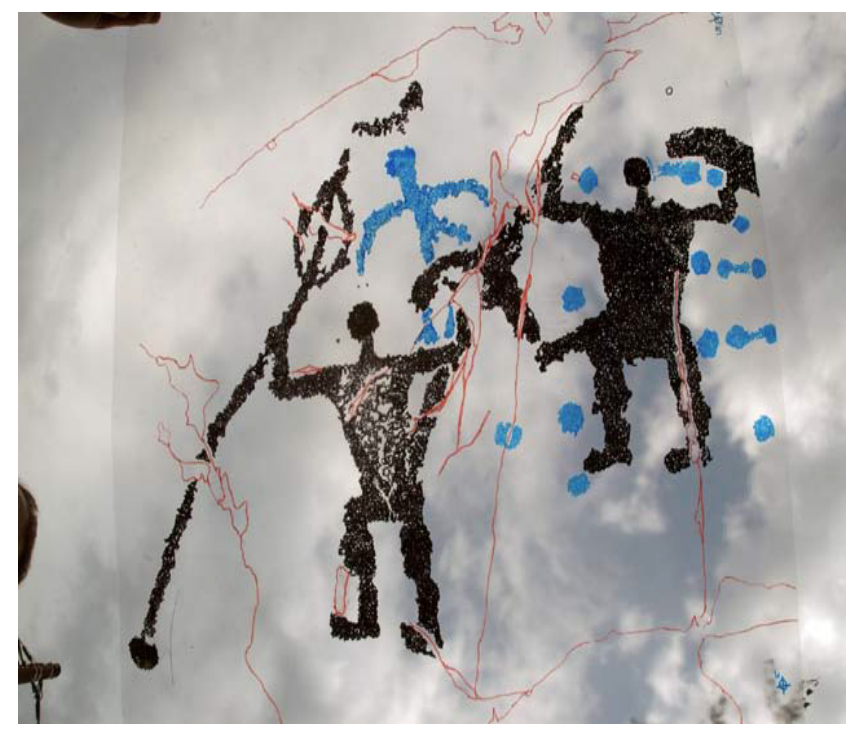

Figure 2. Pagherina R. 2. Pair of warriors from medium- Iron Age in overlapping forms of cups and schematic anthropomorphic (in blue) of the Bronze Age. (Relief Valcamonica and Lombardy Department of the CCSP)

It follows an economic and demographic Continental exploit, that reflects on the rocks, some of the same symbols of the Late Copper Age, although selected, in a reduced range, with some variants, and between these the main element is to be found the weapons again. So in Alps we discover a circumscribed rock phenomenon. Very different and strong from what happens on a continental level, with good examples in the Iberian Peninsula, in the British Isles, in the Centre Europe and in Scandinavia.

\section{Representation and Symbolism of Weapons}

In the Alps are to be found one of the most impressive collections of carved images of weapons and warriors. In 
places where it developed the phenomenon of ceremonial sites with steles and carved boulders, along the valleys dell'Isarco, the Adige, the Adda, Oglio, the Upper Rhone, the Dora Baltea and Magra, in the Apennines. At the center of the context, the Media Valcamonica and the Media Valtellina both expressing a cohesive and conceptually imagery of weapons.

In the precise symbolic framework: axes and halberds, often in couple, usually are at the top, also the solar disc and zoomorphic (ibex, deer), as daggers normally in dense series in the central part, along with anthropomorphic and / or zoomorphic (deer, mountain goats, wolves, wild boars, pigs or deer) while appear at the bottom plowing or furrows plowing [3, p.18].

Usually the long-handled weapons, axes and halberds, are therefore indicated in the high part of the composition, in clear relationship with the solar disk. then with the celestial sphere, daggers generally in higher number, are in the medium context, with anthropomorphic and elements of the world of man or as seem to refer to it, perhaps as a specific individual emblems, almost always figured in a horizontal position, and probably they have a particular combination with the plowing Both in Valcamonica and also on the second largest alpine environment, Mount Bego [12,13] This area is clearly a male sphere, but there are exceptional cases which also combine the symbols of feminine type with beams lines, as it appears in some compositions likely uterus symbols and aviator pendants.

It proposes again the parallel with the burial customs of the time where we could find weapons (daggers, axes, arrowheads) in not only male burials but in few details cases, with dubious valence of weapon, also in the women's and infant ones [3].

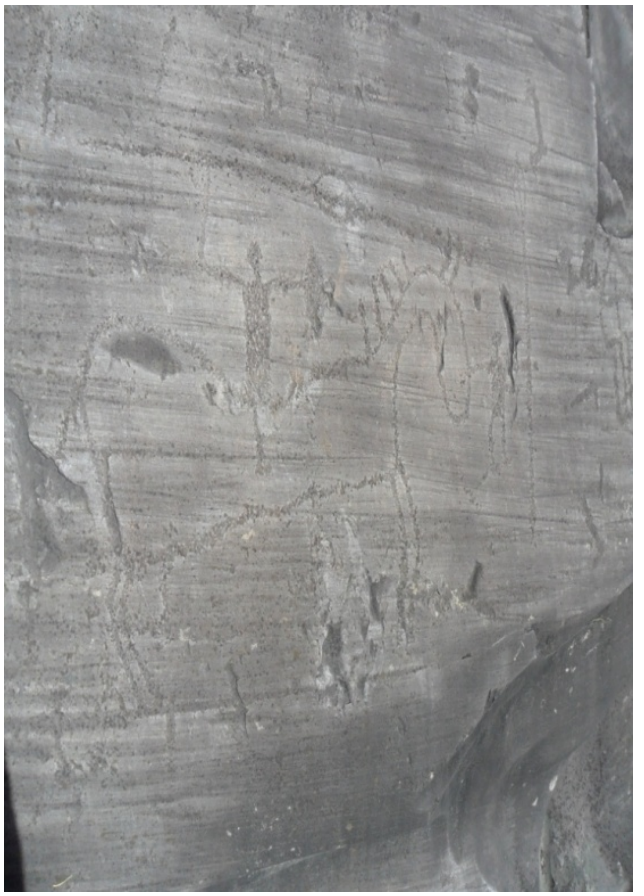

Figure 3. Foppe di Nadro R. 26-27 (Author photograph)
As one of many examples we can discover in Valcamonica, in the rock number 26-27 of Foppe di Nadro, are to be seen some notable pieces of carved work. It has the representation of a horse with the rider and the squire on foot. The size of the horse seems to reflect the importance given to the horse as a status symbol during the Iron Age and the warrior, armed with spear and shield. It seems also to emphasize a clear distinction between the roles of the knight and squire, in which the class that struggle and defend the community has a key role and a major importance. Representations of Knight or warriors and scenes of combat are quite common, however the representation of weapons is massive everywhere, in the rock carvings or in the steles.

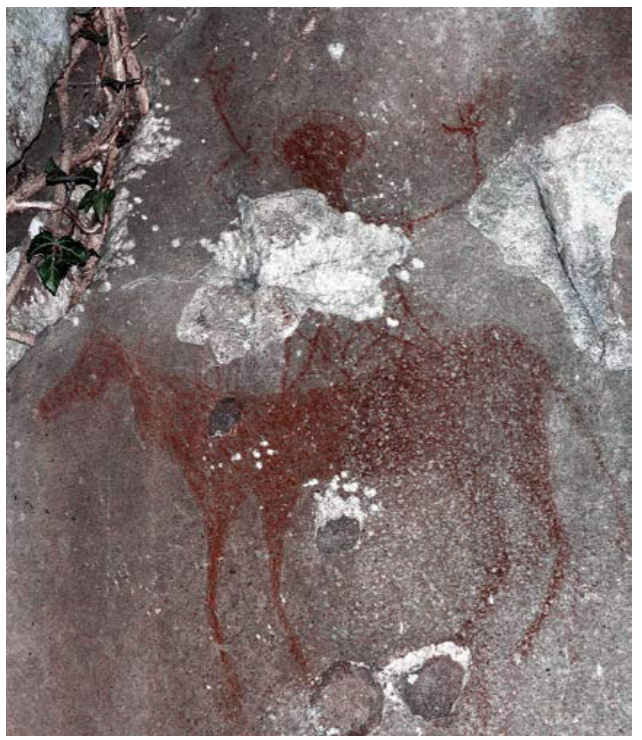

Figure 4. Paspardo gorge of the King, the"Red Knight" (Photo M. Colella -reworked)

In Paspardo, on Gorge of the King, we can find the "Red knight" on rock number 3 (Cittadini, 1994, p.12), one of the rare surviving paintings in a vertical wall. An elegant silhouette of horse, unfortunately vandalized, shows details such as the dignity of the robe, the helmet ridge lines and the particular crescent of the ax blade [14\}. From late Iron Age, probably IV-II sec. B.C.

\section{Steles of Naquane}

The steles are stone monuments, of anthropomorphic type, within the megalithic phenomenon, common to the pre-protohistoric European peoples from the third millennium B.C. The steles as large carved stone blocks with different motifs bring some new insights for the knowledge of past societies. Valcamonica as a very interesting lot of this monuments, were we also benefit from a major representation of weapons and of warriors as some other motifs, which help us to better understand some big rock art panels.

Generally there is a prior preparation of the surface to be 
engraved, flattening the rock support, ranging from shale, limestone and granite. The reasons are executed by perforation, normally followed up by a careful abrasion which results in a beautiful polishing aesthetic effect. After finishing the stele was stuck in the ground and placed vertically.

Typologically there are some differences between these steles [7]. Thus, there are cases only with the shield representation, sword or dagger and spear (so-called tripartite stele), while other specimens have higher amount of iconographic elements.

The stele-statues may depicting stylized characteristics which cover men, in their role as warriors and thus armed with daggers and sometimes spear points, or women, constantly characterized by the presence of breasts and, sometimes, of ornaments. In the stele-statues was not given importance to the physical features of the face, often only hinted at or made with abstract graphic elements (face T, typical of Lunigiana steles and steles from Sardinea). Other parts of the body, usually are omitted and the arms and feet often as well, are represented only in very rare (and later) specimens.

The shields can be represented only by concentric circles, have more or less details, or representation of the clan, as well as decorative elements. In some cases, engravings as small dimples represent the metal studs. The daggers are the elements fairly represented on stele, coming either from a very schematic way, or more elaborated. The daggers and other weapons as mentioned before, are generally well represented numerically and provide an extraordinary iconographic documentation.

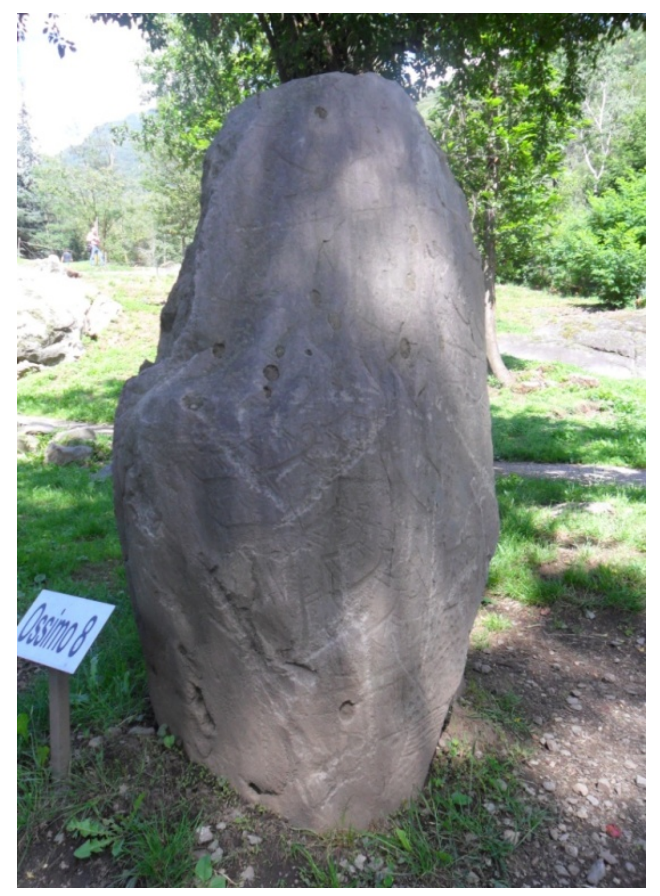

Figure 5. Naquane stele from Ossimo 8 (Author photograph)

The steles found in Valcamonica were so far found in. archaeological excavations and have confirmed their presence around places of prehistoric veneration, especially in various locations near the town of Ossimo (Asinino-Anvòia, Passagròp and Pat) and Cemmo (Pian delle Greppe).

The daggers engraved on the surfaces, type "remedelliano", and the shape of the blade axes and halberds, allow an approximate dating of the stele align to the third millennium BC.

Compared to other groups of stone-statues in Valcamonica many of these monuments have a kind of human form, but they have representations of different symbols. like animals (deer, ibex, chamois, dogs and Suede), weapons (daggers, halberds, and axes), solar discs, female jewelry (coulombs double spiral, collars etc.) and also human figures. Sometimes scenes are also represented plowing scenes and, more rarely, "topographic maps" (ibid.).

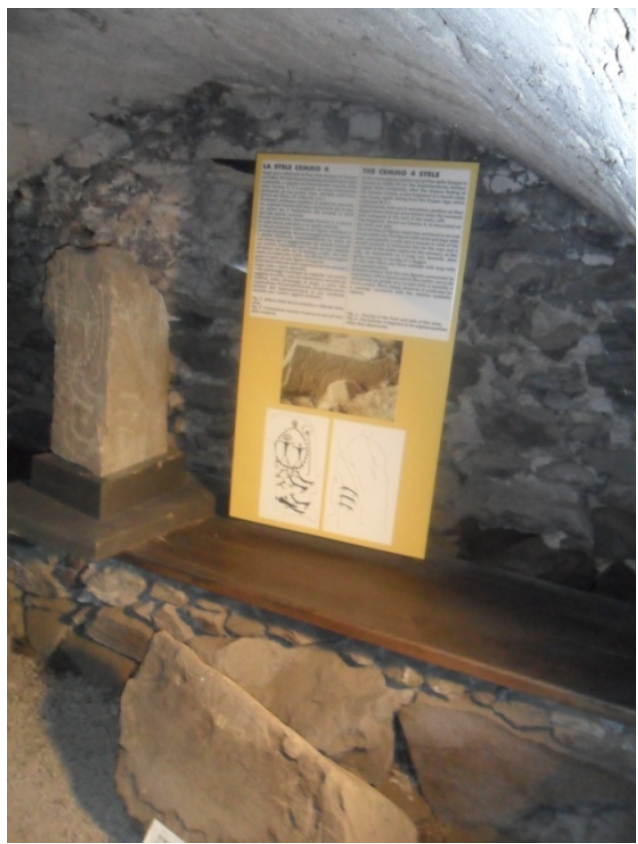

Figure 6. Naquane inside the house-museum with steles (Author photograph)

In the rock art Park of Naquane, besides some impressive huge panels with dozens of engraved motifs we can find also several steles from different parts of the entire Valcamonica that are exposed there. In some cases like in figure 5 they are outside with a small plaque with the name of the place where it comes from. In other cases they are reunited in a small house/museum that hosts the ones that are more vulnerable to be in the open air all year. The figure 6 show a small corner, inside the room that shelter the monuments, were we can see steles and panels with more detail information about it.

Naquane is one of the most visited parks in all Valcamonica and it was the first to be made in 1955. It belongs to Italian state and is under the supervision of Minestero per $i$ Beni e le Attività Culturali and Soprintendenza per I Beni Archeologici della Lombardia. Naquane offers a very specific and special overview with a 
great concentration of rock engravings. We should particularly take account of the "Big rock" with more than 800 figures, in which it can be found hunting scenes, cars, maps, dears with solar antlers as other animals, the "camuna" rose, feet, geometric signs, duel scenes and off course, lots of daggers, our most common weapon depicted here, but also halberds and axes.

\section{Closing Remarks}

Valcamonica convey eighth Parks that are under different administration and jurisdiction, but in general all seems to work well, and local as several international institutions continuous to invest in promote the rock art field of knowledge. In Valcamonica, on the gray polished rocks by the action of glaciers, the communities that have lived there, produced images recording on the rock with lytic or metal tools. Those populations lead a legacy that had as themes, symbolic objects, tasks or events of their everyday life or of their spiritual work, recharged of great symbolism, left in a large collection of depictions.

The large amount of depictions of weapons makes this place an important source for research in old weaponry. The weapons play a major role as status symbols and vital tools in battle. The weapons are also invaluable documents to get to know society, history and tastes of the people. Under the erosion of time and the elements, the rock art is unraveling the original appearance of daggers and other weapons as halberds, or helmets and shields. The analyses that glimpse at those testimonials have an astonishing value, for they portrait an important part of past society.

Old weapons have a technological facet. Metallurgy weaponry, either bronze or iron, picked the best that was produced with the available technology in a certain period. Therefore, the arms are susceptible to be studied from that perspective and provide a lot of information of the past.

We can also address the study from the functional point of view, it means how it is fought, the capacity and which they had lacked, and from there to obtain data on the forms of combat, military tactics and even culture, in a broad sense [15]. It will be wise not to forget that combat forms and articulation of society are obverse and reverse of the same coin in Ancient Greece and Rome as in other cultures from Iron Age. The society was organized on essentially military bases, question that in the case of Rome or Greece, is documented by literary sources (ibidem).

Some of its decorations and particular forms contribute to the distinction and empowerment of its user bringing external signs of respect. All these features contribute to the warrior living in an atmosphere of pride, superiority and bright aura. After all, warriors were the class that defend and allowed the perpetuation of that society.

The weapon could also be viewed as an art object, functioning as a support for an aesthetic expression loaded of meaning. Among the many categories of objects that produced the Iron Age culture, weapons truly add perhaps more than any other, all those social, technological, symbolic and religious connotations that turn them into a special category worth to be studied.

\section{REFERENCES}

[1] Anati E., Capire lárte rupestre. Studi camuni, vol. 26, Edizioni del Centro, Capo di Ponte, 2007.

[2] Anati, E., World Rock Art, Archaeopress, Oxford, 2010.

[3] Sansoni U., VII millennio a.C.-XIV secolo d.C. Armi ed armati nell'arte rupestre della Valcamonica In, Brumana, A. Ferragio and E. Grunta F. (eds) Brescia contesa: 14-34, Brescia: Edizioni Misinta, 2013b.

[4] Sansoni U., Gavaldo S., Gastaldi C. Simboli sulla roccia, Edizione Del Centro, Capo di Ponte, 1999.

[5] Sansoni U., Marretta A., Lentini S, Il segno minore: arte rupestre e tradizione nella Bassa Valcamonica (Pisogne e Piancamuno, Archivi 14 CCSP, Capo di Ponte, 2001 pp11-38.

[6] AA.VV., Valcamonica Symposium XXI-XXIV, Capo di Ponte (Edizioni del Centro), 2004-2011.

[7] Anati E., The alpine menhir-statues and the indoeuropean problem, in BCSP 25-26, Edizioni del Centro, Capo di ponte, $1982 \mathrm{~b}$.

[8] Anati, E.,. I segni della storia, Roma Di Renzo Editore, 1997.

[9] Anati, E., Grafismo e semiotica, BCSP n.31-32, Edizioni del Centro, Capo di Ponte, 1999.

[10] Anati, E., Lo stile come fattore diagnostico nell'arte preistorica. Edizioni del Centro, Capo di Ponte, 2002.

[11] Fossati A., Le armi nell'arte rupestre dell'età del Bronzo. Depositi votivi di sostitutivi e rituali iniziatici nelle Alpi, in Archeologia e arte rupestre: l'Europa, le Alpi, la Valcamonica - atti del secondo convegno internazionale di arqueologia rupestre, 2-5 ottobre 1997 Darfo Boario Terme, 1997,pp. 105-112.

[12] ARCÀ A., "Chronology and interpretation of the "praying figures' in Valcamonica rock art", in Archeologia e Arte Rupestre. L'Europa - Le Alpi - La Valcamonica, secondo convegno internazionale di archeologia rupestre (2-5 ottobre 1997, Darfo Boario Terme), Milano, 2001, pp. 185-198.

[13] Sansoni U., Gavaldo S., L'arte rupestre del Pià d'Ort. La vicenda di un santuário preistorico alpino, in archivi vol. 10, Edizioni del Centro, Capodiponte, 1995.

[14] Cittadini T., Pitture rupestri in Valcamonica, in "Archeologia viva", 48, 1994 p. 12.

[15] Quesada Sanz, F., Arte sobre Metal: el armamento prerromano, Stilus 5, 2008, pp 28-33. 